\title{
The Effect of Basic Position Training on Walking Abilities of Visually Impaired Individuals
}

\author{
Ceren Suveren-Erdoğan ${ }^{1}$, Fatmanur $\operatorname{Er}^{2} \&$ Sibel Suveren ${ }^{1}$ \\ ${ }^{1}$ Faculty of Sport Science, Gazi University, Ankara, Turkey \\ ${ }^{2}$ Faculty of Sport Science, Atatürk University, Erzurum, Turkey \\ Correspondence: Ceren Suveren-Erdoğan, Faculty of Sport Science, Gazi University, Ankara, Turkey.
}

Received: June 1, $2018 \quad$ Accepted: June 29, $2018 \quad$ Online Published: July 20, 2018

doi:10.5539/jel.v7n5p130 URL: https://doi.org/10.5539/jel.v7n5p130

\begin{abstract}
Objective of this study is to help the basic standing position training to take its part among basic exercises of the visually impaired individuals, and to observe the effects of this training on walking and balance skills.

Method: 8 visually impaired sedentary individuals with impairment levels of B1 and B2 and ages of 18 to 24 voluntarily participated in the study. After acknowledging the visually impaired individuals with audial information regarding the study, they were told to brisk walk for 15 steps against the audio signal and then to heel-to-toe walk for 15 steps. Their corresponding walking distances, walking durations, directional impairments and losses of balance were recorded. During the 8 week period following this test, 45 minute training sessions accompanied by trainers that included 4 basic standing positions and their combinations were applied once a week, where the trainer corrected the individuals verbally and physically. Abovementioned tests were repeated after these 8 weeks. Gender categorization was not made since the participants were few in number. Non-parametric Wilcoxon Signed Rank Test was applied and a significant increase for the pretest was observed at a 0.05 significance level, where the distances walked increased and walking durations along with losses of balance decreased.

Result: It was observed that walking skills of visually impaired individuals that received verbal and physical assistance, and that effectively performed basic positions and their combinations were smoother and more confident; that their walking distances were increased, their losses of balance were decreased and that they encountered less deviations from the direction of movement while walking, compared to their pretest conditions. Starting from this point of view, it might be concluded that the basic standing positions were highly beneficial and applicable activities for walking training of visually impaired individuals.
\end{abstract}

Keywords: visual impairment, basic standing positions, walking skills

\section{Introduction and Objectives}

Directly proportional to the emergence of impairment, balance skills and perception of obstructions might develop late for visually impaired individuals. This results from the fact that, being able to see a point of reference supports awareness of bodily position and the capability of preserving stability, along with adaptation of the body to new positions (Casselbrand et al., 2007).

Identifying needs of visually disabled individuals and preparing exercise programs specifically designed for them improves these individuals' quality of life (Winnick, 2017; Gallahue, 1987). By arranging contents of these exercises so that they would contain kinesthetic and audial stimulants, development of motor skills can be contributed and losses of balance could be decreased to a lesser extent (Suveren, 2003; Deliceoğlu et al., 2017; Murphy, 1989; Pogrund et al., 1998).

Visual impairment is defined as, "a loss of sight that adversely affect a child's academic achievements" (Craft, 1995).

Problem of independent mobility that the visually impaired individuals encounter is reflected in a negative manner in terms of their social lives, which in turn leads to loss of motivation (Coughlan et al., 2012; Horak, 1987; Havik et al., 2010; Deliceoğlu et al., 2017; Arslantekin, 2014; Montarzino et al., 2007). Realization of spatial and bodily awareness increases disabled individuals' mobility (Kalia et al., 2010; Altunay, 2003). 
Independent mobility is directly proportionate to skills such as walking, posture and capability of body control (Yilmaz et al., 2013; Pogrund et al., 1998).

Problems with walking for visually impaired individuals are observed as slow walking, short length of stride, stiffness in forward moving legs, waddling and barely touching of heels to the ground, stillness or little movement of the body, little movement of arms or defensive walking by extending arms forward as if an obstruction would be faced any minute; and these distinct postures \& patterns of walking make children perceived as out of the ordinary by the people surrounding them (Tuncer et al., 1999).

Objective of this study is to help the basic standing position training to take its part among basic exercises of the visually impaired individuals and to observe the effects of this training on walking and balance skills.

\section{Method}

8 visually impaired sedentary individuals with impairment levels of B1 and B2 and ages of 18 to 24 voluntarily participated in the study. They were told to brisk walk for 15 steps against the audio signal and then to heel-to-toe walk for 15 steps. Their corresponding walking distances, walking durations, directional impairments and losses of balance were recorded. During the 8 week period following this test, 45 minute training sessions accompanied by trainers that included 4 basic standing positions and their combinations were applied once a week, where the trainer corrected the individuals verbally and physically. Basic position exercises were chosen for having characteristics such as not requiring changing locations, not creating problems with respect to perception of obstructions, meeting the demand for handicapped individual's movement and increasing self-confidence. Abovementioned tests were repeated after these 8 weeks. Gender categorization was not made since the participants were few in number. Non-Parametric Wilcoxon Signed Rank Test was applied to identify whether a significant difference existed between the subjects' pretest and posttest scores.

\subsection{Contents of the Exercise}

a. Basic Positions
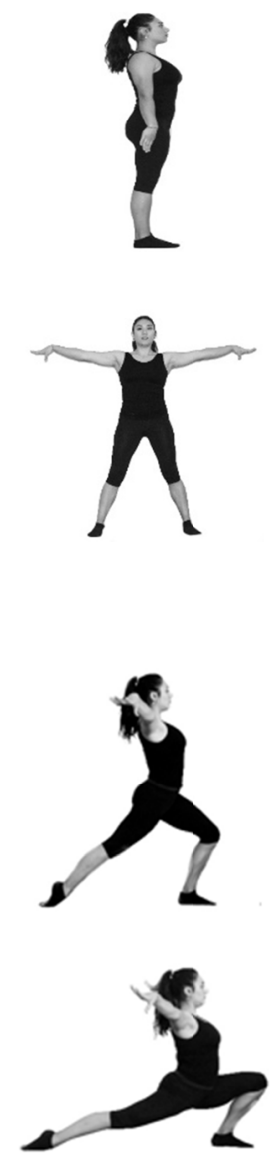

1. Basic Position: Legs should be closed, the core should be straight (kept in), the head should be in natural position as the continuum of the spine and the arms should be tight on both sides.

Objective: To keep the head straight while walking and to help sustaining upright bodily position, to allow the feet point the direction of walking and to prevent directional impairment.

2. Legs Apart Position: One of the legs steps apart from the other at least in shoulder-width while in basic position, and the position is kept steady. Show the same characteristics with the basic position. The only difference is that the legs and arms extending to sides. The arms should be parallel to the ground and exactly on both sides.

Objective: Correct positioning of head and arms while performing this position, body control in different positions of the body and keeping balance.

3. Forward Lunge - Forward Wide Lunge: A wide step is taken from the basic position and as the weight is transferred the front leg is bent at the knee, while the rear leg is kept straight. Arms should be on both sides or in front and parallel to ground, head should be in natural position, feet in line with each other and the toes should be pointing exactly right across the individuals.

Objective: Transfer of center of gravity (forward-backward), keeping balance, awareness of body position, determining the direction of movement, body control, improvement of skills of independent movement and flexibility. 

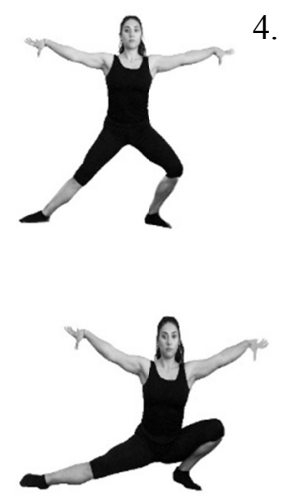

4. Side Lunge - Wide Side Lunge: The move starts with legs apart standing position. The knee which the weight is transferred is bent as weight is transferred to sides, while the other knee is kept straight.

Objective: Transfer of center of gravity (right-left), keeping balance, awareness of body position, determining the direction of movement, body control, improvement of skills of independent movement and flexibility.

Hip-Shoulder square (keeping the shoulders and hips in parallel on the same plane) was especially observed and mistakes were corrected with the trainer's verbal and physical guidance.

b. Combinations of Basic Positions

1. Raising and lowering arms and forward/backward circles while in basic position

2. Knees bent squats in legs apart basic position

3. Wide lunge to right and left sides starting from legs apart basic position

4. Forward lunge from basic position and coming back to basic position (with right and left foot)

5. Transition from legs apart position to forward lunge with $1 / 4$ turn followed by another $1 / 4$ turn to side lunge, then $1 / 4$ turn by transferring weight and forward lunge with the other leg, concluded by coming back to starting position.

\subsection{Training Program}

Table 1. Periodization

\begin{tabular}{|c|c|c|c|c|}
\hline Week & 1 & 2 & 3 & 4 \\
\hline Set & 2 & 2 & 2 & 2 \\
\hline Rep & 5 & 5 & 5 & 5 \\
\hline Time (sec) & $5 \times 30^{\prime \prime}$ & $5 \times 30^{\prime \prime}$ & $5 \times 30^{\prime \prime}$ & $5 \times 30 "$ \\
\hline Rest (sec) & $5 \times 30^{\prime \prime}$ & $5 \times 30 "$ & $5 \times 30^{\prime \prime}$ & $5 \times 30 "$ \\
\hline Training Mode & $\mathrm{BP}+\mathrm{OBP}+\mathrm{FM}+\mathrm{SM}$ & $\mathrm{BP}+\mathrm{OBP}+\mathrm{FM}+\mathrm{SM}$ & $\mathrm{BP}+\mathrm{OBP}+\mathrm{FM}+\mathrm{SM}$ & $\mathrm{BP}+\mathrm{OBP}+\mathrm{FM}+\mathrm{SM}$ \\
\hline Week & 5 & 6 & 7 & 8 \\
\hline Set & 2 & 2 & 2 & 2 \\
\hline Rep & 5 & 5 & 5 & 5 \\
\hline Time (sec) & $5 \times 30^{\prime \prime}$ & $5 \times 30^{\prime \prime}$ & $5 \times 30 "$ & $5 \times 30^{\prime \prime}$ \\
\hline Rest (sec) & $5 \times 30^{\prime \prime}$ & $5 \times 30^{\prime \prime}$ & $5 \times 30^{\prime \prime}$ & $5 \times 30 "$ \\
\hline Training Mode & $\mathrm{BPC}+\mathrm{OBPC}+\mathrm{FMC}+\mathrm{SMC}$ & $\mathrm{BPC}+\mathrm{OBPC}+\mathrm{FMC}+\mathrm{SMC}$ & $\mathrm{BPC}+\mathrm{OBPC}+\mathrm{FMC}+\mathrm{SMC}$ & $\mathrm{BPC}+\mathrm{OBPC}+\mathrm{FMC}+\mathrm{SMC}$ \\
\hline \multicolumn{5}{|c|}{ 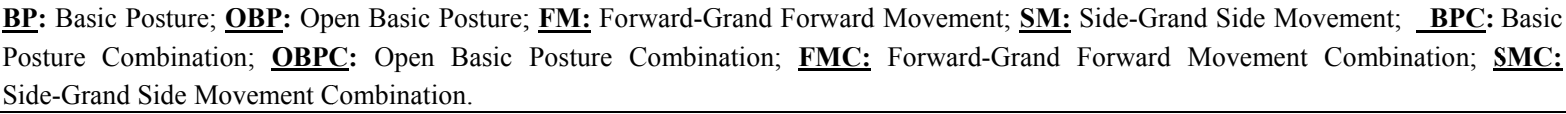 } \\
\hline
\end{tabular}

\section{Findings}

Table 2. Pretest and Posttest 15 B.S.D, 15 S.H.T.L.B, 15 B.S.T, 15 S.H.T.T values

\begin{tabular}{|c|c|c|c|c|c|c|}
\hline & $\begin{array}{c}\text { Pretest } \\
\bar{x} \\
\end{array}$ & $\begin{array}{l}\text { Pretest } \\
\text { SD. }\end{array}$ & $\begin{array}{c}\text { Posttest } \\
\bar{x} \\
\end{array}$ & $\begin{array}{l}\text { Posttest } \\
\text { SD. }\end{array}$ & $z$ & $p$ \\
\hline 15 B.S.D $(\mathrm{m})$ & 8.93 & 2.11 & 12.16 & 1.70 & -2.251 & $.012 *$ \\
\hline 15 S.H.T.L.B & 7.37 & 2.72 & 1.87 & 1.45 & -2.536 & $.011 *$ \\
\hline 15 B.S.T $(\mathrm{sec})$ & 11.37 & 2.06 & 9.52 & 1.69 & -2.384 & $.017 *$ \\
\hline 15 S.H.T.T $(\mathrm{sec})$ & 28.62 & 5.26 & 12.00 & 2.72 & -2.524 & $.012 *$ \\
\hline
\end{tabular}

Notes. ${ }^{*} \mathrm{p}<0.05$.

15 B.S.D: 15 Brisk Step (Distance)

15 S.H.T.L.B.: 15 Steps Heel-to-toe Loss of Balance

15 B.S.T: 15 Brisk Step Duration

15 S.H.T.T: 15 Steps Heel-to-toe Duration 
A significant increase for the pretest was observed at a 0.05 significance level as a result of the study, where the distances walked increased and walking durations and loss of balance values decreased.

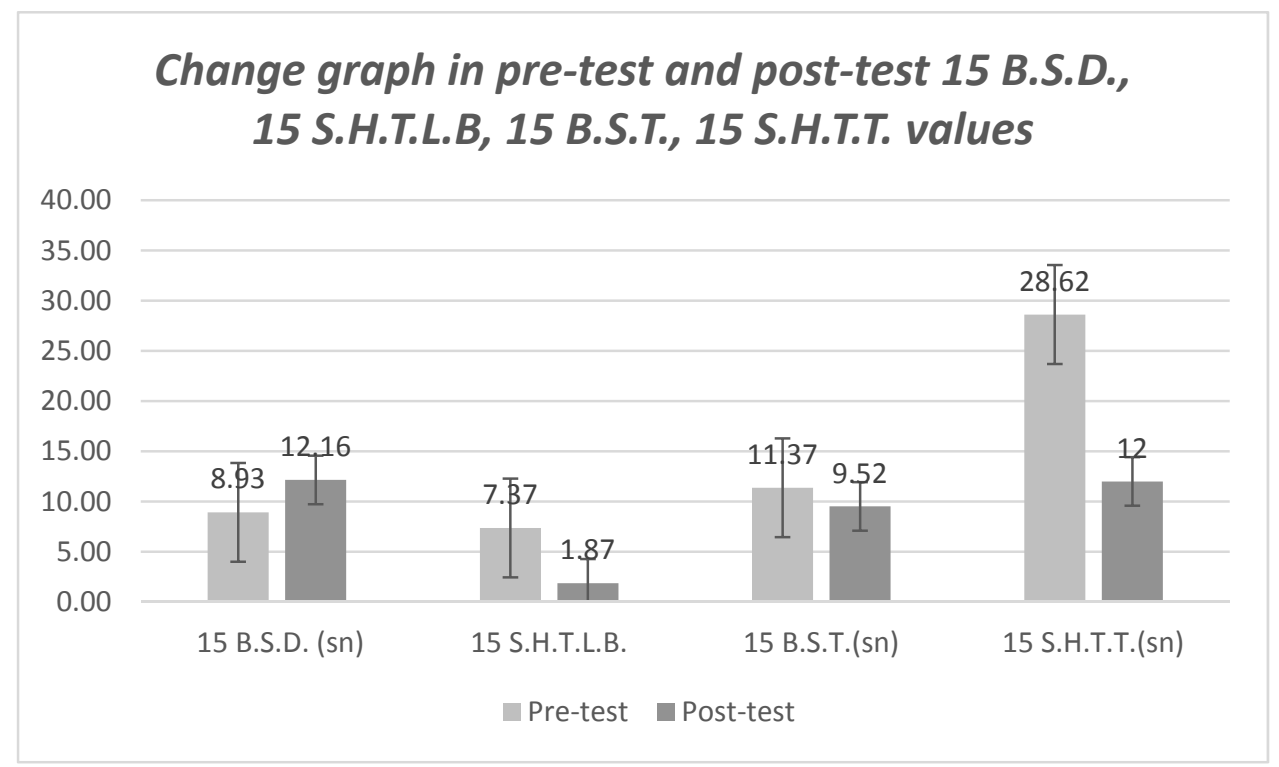

Graph 1. Pretest and Posttest 15 B.S.D, 15 S.H.T.L.B, 15 B.S.T, 15 S.H.T.T values

\section{Discussion and Conclusions}

The only way that the motor development process for visually impaired individuals can proceed like it does for normal individuals is through the application of a training system similar to that of visually healthy individuals (Pogrund and Fazzi, 2002)

It was reported in the family guidance book prepared by Robinson and Lieberman (2007) that the verbal and physical support was vital in terms of exercise applications for visually impaired individuals.

Pogrund, R. L., Healy et al. (1998) mentioned in their book how important was the teaching method using audial stimulants and applications assisted by walls regarding development of attention and improvement of their posture and walking.

Teaching of independent mobility skills for the visually impaired aim to develop correct postures and to help them walk naturally (Altunay, 2003).

Ak1 et al. (2007) applied a motor skills training program on partially-sighted children and investigated the efficiency of this training. Improvements were achieved in terms of all the activities along with an improvement in balance-keeping skills, which was in line with current study's findings.

Akyol et al. (2017) stated that visually impaired individuals might become more independent in their daily activities if they would be directed towards sports, by coming into a conclusion that sports had positive effects on balance and the walking distance. Research findings are compatible with this outcome in all aspects.

Seok-Min et al. examined static and dynamic balance performances of Goalball and Track and Field Athletes, and they similarly used the brisk walk as the dynamic balance performance test. After the training program was applied, it has been observed that the step frequency post-test values of the sedentary individuals participating in the study were similar to those of the athletes participating in Seok-Min et al.'s study (Goalball $77.66 \mathrm{~cm}$ and Track and Field Athletes $69 \mathrm{~cm}$ ).

At the end of the rope jumping and strength exercises that Urhan (2018) applied on visually impaired children, he conducted a 1-mile run-walk-run test, -and besides other findings- he achieved an improvement in walking durations, which was in line with this study's findings.

Chen et al. (2011) examined the impact of Tai Chi exercises on balance development in their study on visually impaired elderly and found improvement in the experiment group in comparison to the control group $(\mathrm{P}=0.024)$. Because the Tai Chi exercises were similar to the head position in the basic position combinations and weight transfer studies, the results of the studies are parallel to one another. 
Suveren-Erdoğan and Suveren (2018) concluded that basic position exercises were highly effective in the development of such characteristics as the perception of obstructions, spatial orientation, postural control, and strength.

Seemungal, Glasauer, Gresty, and Bronstein (2007) suggested that long-term training for blind people could affect navigation and orientation (a function of the vestibular system). Jazi et al. (2012) applied an 8-week equilibrium training on visually handicapped children and observed the development of dynamic equilibrium; they indicated that the preservation of balance depends partly on how the vestibular system works. As a result, they noted a significant improvement in both intra-group and inter-group equilibrium performances of the experiment group similar to this study $(\mathrm{t}(18)=4.095, \mathrm{p}<0.05)$. They argued that the vestibular system is another factor contributing to the stabilization of individuals with visual impairment, it affects, in general, the somatosensory system and in particular the equilibrium state of proprioceptive, and thus the kinaesthetic sensations in joints can develop after an eight- week equilibrium training (Jazi et al., 2012)

While the basic position combinations, weight transmissions and a shift in the directions in the conducted study were considered to be effective on the vestibular system as well, when the data were evaluated, it was concluded that the basic standing positions were rather beneficial and applicable exercises in the walking training of visually impaired individuals.

Evaluating findings attained from the study, it was concluded that the basic standing positions were highly beneficial and applicable activities for walking training of visually impaired individuals.

In conclusion, it was observed that walking skills of visually impaired individuals who received verbal and physical assistance and successfully performed basic positions and their combinations were smoother and more confident, besides, their walking distances increased, their losses of balance decreased and they encountered fewer deviations from the direction of movement while walking, in comparison to their pre-test conditions.

\section{References}

Ak1, E., Atasavun, S., Turan, A., \& Kayıhan, H. (2007). Training Motor Skills of Children with Low Vision. Perceptual and Motor Skills, 104, 1328-1336.

Akyol, B., Konar, N., \& Taş̧̧ı, M. (2017). The Effect Of Sport On Balance And Walking Distance With Visually Impaired People, 12. Niğde University Beden E ğ itimi Ve Spor Bilimleri Magazine, 11(3).

Altunay, B. (2003). Görme yetersizliği olan çocuklarda yönelim ve bağımsız hareket becerileri. In U. Tüfekçioğlu (Ed.), İsitme, konuşma ve görme sorunu olan çocukların eğitimi (pp. 275-300). Eskişehir: Anadolu University Press.

Arslantekin, B. (2014). The Effects of Visual Impairment on Psychomotor Development and Independent Mobility and Supportive Programs. Ergoterapi ve Rehabilitasyon Magazine, 2(3), 165-175. Retrieved from http://dergipark.gov.tr/ered/issue/33219/369671

Casselbrand, M. L., Mandel, E. M., Sparto, P. J., Redfern, M. S., \& Furman, J. M. (2007). Contribution of vision to balance in children four to eight years of age. Journal of Ontology, Rhinology, \& Laryngoloy, 116(9), 653-657.

Chen, E. W., Fu, A. S., Chan, K. M., \& Tsang, W. W. (2011). The effects of Tai Chi on the balance control of elderly persons with visual impairment: a randomised clinical trial. Age and ageing, 41(2), 254-259. https://doi.org/10.1093/ageing/afr146

Coughlan, G. F., Fullam, K., Delahunt, E., Gissane, C., \& Caulfield, B. M. (2012). A comparison between performance on selected directions of the star excursion balance test and the Y balance test. Journal of athletic training, 47(4), 366-371. https://doi.org/10.4085/1062-6050-47.4.03

Craft, D. H. (1995). Visually impairments and hearing losses. Adapted physical education and sport.

Deliceoğlu, G., Çavuş, T. P., Karaman, G., Kocahan, T., Tortu, E., \& Tekçe, A. (2017).Goalball Antrenmanının Kadın Goalball Paralimpik Takımının Kuvvet, Denge ve Esneklik Parametrelerine Etkisinin İncelenmesi. Gaziantep University Spor Bilimleri Magazine, 2(1), 74-84.

Gallahue, D. L. (1987). Developmental Physical Education for Today's Elementary School Children: Instructor's Resource Manual with Transparency Masters. Macmillan.

Havik, E. M., Steyvers, F. J. J. M., Van der Velde, H., Pinkster, J. C., \& Kooijman, A. C. (2010). Design and evaluation of a protocol to assess electronic travel aids for persons who are visually impaired. Journal of Visual Impairment \& Blindness, 84-94. 
Horak, F. B. (1987). Clinical measurement of postural control in adults. Physical Therapy, 67(12), 1881-1885. https://doi.org/10.1093/ptj/67.12.1881

Jazi, S. D., Purrajabi, F., Movahedi, A., \& Jalali, S. (2012). Effect of selected balance exercises on the dynamic balance of children with visual impairments. Journal of Visual Impairment \& Blindness, 106(8), 466.

Kalia, A. A., Legge, G. E., Roy, R., \& Ogale, A. (2010). Assessment of indoor route finding technology for people who are visually impaired. Journal of Visual Impairment \& Blindness, 104(3), 135-147.

Montarzino, A., Robertson, B., Aspinall, P., Ambrecht, A., Findlay, C., Hine, J., \& Dhillon, B. (2007). The impact of mobility and public transport on the independence of visually impaired people. Visual Impairment Research, 9, 67-82. https://doi.org/10.1080/13882350701673266

Murphy, M. F. (1989). O'drriscoll M. Observations on the Motor Development of Visually Impaired Children. Physiotherapy, 75(99), 505-508. https://doi.org/10.1016/S0031-9406 (10)62300-0

Pogrund, R. L., \& Fazzi, D. L. (2002). Early Focus: Working with young children who are blind and visually impaired and their families (2nd ed.). New York: AFB Press.

Pogrund, R. L., Healy, G., Jones, K., Levack, N., Martin- Curry, S., Martinez, C., Marz, J., Roberson-Smith, B., \& Vrba, A. (1998). TAPS: Teaching age-appropriate purposeful skills: An orientation and mobility curriculum for students with visual impairments (2nd ed.). Austin: Texas School for the Blind and Visually Impaired.

Robinson, B., \& Lieberman, L. J. (2007). Influence of a parent resource manual on the physical activity levels of children with visual impairments. RE View, 39(3), 129-139. https://doi.org/10.3200/REVU.39.3.129-140

Seemungal, B. M., Glasauer, S., Gresty, M. A., \& Bronstein, A. M. (2007). Vestibular perception and navigation in the congenitally blind. Journal of Neurophysiology, 97, 4341-4356.

Seok-Min, Y., Silliman-French, L., \& HyunSu, L. (2010). Comparison of static and dynamic balance of youth goalball and track and field athletes with visual impairments: Case study. Journal of Sport and Leisure Studies, 40, 455-462.

Suveren, S. (2003). Görme Engellilerde Serbest ve Aletle Cimnastik Çalışmaları "G.Ü.B.E.S.Y.O.”. Physical Education and Social Fields in Sports Congress, 10-11 October 2003 Ankara, pp. 91-95.

Suveren-Erdoğan, C., \& Suveren, S. (2018). Teaching of Basic Posture Skills in Visually Impaired Individuals and Its Implementation Under Aggravated Conditions. Journal of Education and Learning, 7(3), 109-116. https://doi.org/10.5539/jel.v7n3p109

Tuncer, T., \& Altunay, B. (1999, Kasım). Route analyses for teaching of orientation and independent mobility skills to visually impaired students, 9th National Special Education Congress, Eskişehir.

Urhan, M. (2018). Az gören çocuklarda ip atlama ve kuvvetlendirme eğitiminin etkinliği (Master's thesis, Pamukkale University, Institute of Health Sciences). Retrieved from http://hdl.handle.net/11499/2437

Winnick, J. P. (2017). Uyarlanmış Beden Eğitimi ve Spor.5. Press. Ekin Kitap Sports and Tourism Press. İstanbul.

Yılmaz, S., Tatar, Y., Ateş, O., \& Tiryaki, E. (2013). Judo Sporunun Görme Engelli Oğrenciler Uzerine Etkisinin Bazi Parametreler Acisindan İncelenmesi. Spor Bilimleri Magazine, 3.

\section{Copyrights}

Copyright for this article is retained by the author, with first publication rights granted to the journal.

This is an open-access article distributed under the terms and conditions of the Creative Commons Attribution license (http://creativecommons.org/licenses/by/4.0/). 